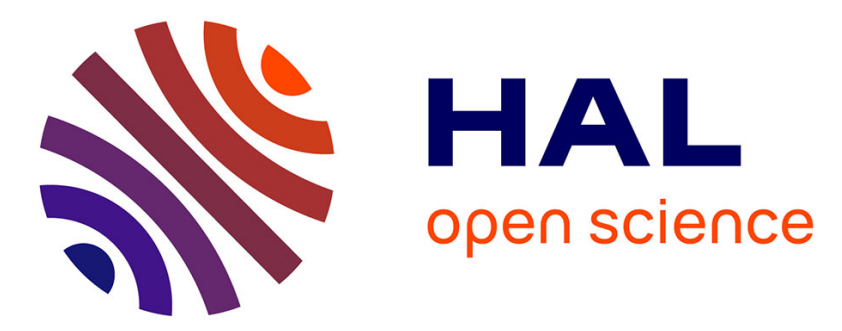

\title{
Comment to: Relationship between the expression of PD-1/PD-L1 and 18 F-FDG uptake in bladder cancer
}

Antoine Girard, Mathieu Rouanne

\section{To cite this version:}

Antoine Girard, Mathieu Rouanne. Comment to: Relationship between the expression of PD-1/PDL1 and 18 F-FDG uptake in bladder cancer. European Journal of Nuclear Medicine and Molecular Imaging, 2019, 46 (6), pp.1212-1213. 10.1007/s00259-019-04296-6 . hal-02127098

\section{HAL Id: hal-02127098 \\ https://hal-univ-rennes1.archives-ouvertes.fr/hal-02127098}

Submitted on 13 May 2019

HAL is a multi-disciplinary open access archive for the deposit and dissemination of scientific research documents, whether they are published or not. The documents may come from teaching and research institutions in France or abroad, or from public or private research centers.
L'archive ouverte pluridisciplinaire $\mathbf{H A L}$, est destinée au dépôt et à la diffusion de documents scientifiques de niveau recherche, publiés ou non, émanant des établissements d'enseignement et de recherche français ou étrangers, des laboratoires publics ou privés. 


\section{Letter to the editor}

Title: Comment to: Relationship between the expression of PD-1/PD-L1 and ${ }^{18} \mathrm{~F}-\mathrm{FDG}$ uptake in bladder cancer

Antoine Girard MD ${ }^{1}$, Mathieu Rouanne MD, $\mathrm{PhDc}^{2,3}$

1. Department of Nuclear Medicine, Centre Eugène Marquis, Université Rennes 1, Rennes, France

2. Department of Urology, Hôpital Foch, Université Versailles-Saint-Quentin-en-Yvelines, Université Paris-Saclay, Suresnes, France

3. INSERM Unit 1015, Laboratoire de Recherche Translationnelle en Immunothérapie (LRTI), Gustave Roussy, Université Paris-Saclay, Villejuif, France

\section{Conflict of Interest or Financial Support: none}

Ethical approval: This article does not describe any studies with human participants performed by any of the authors.

Key Words: ${ }^{18}$ F-FDG PET, Bladder Cancer, PD-1/PD-L1 expression, Immunohistochemistry, Immunotherapy

Word count: Text: 623 words

\section{Corresponding author:}

Antoine GIRARD, MD

For and on behalf of all authors

Department of Nuclear Medicine, Centre Eugène Marquis, Université Rennes 1, Rennes, France

Ph: 0033633836888

Fax: 0033299253155

E-Mail: a.girard@ rennes.unicancer.fr 


\section{Letter to the editor}

Title: Comment to: Relationship between the expression of PD-1/PD-L1 and ${ }^{18}$ F-FDG uptake in bladder cancer

\section{Text:}

\section{Dear Sir,}

The study by Chen, et al. addresses an important question regarding the predictive value of ${ }^{18} \mathrm{~F}$ FDG uptake to assess PD(L)-1 expression in bladder cancer [1]. Arguably, this innovative study is of major interest as multiple issues hamper the standardization of programmed cell death ligand-1 (PD-L1) scoring in tumour tissue. Recently, the Food and Drug Administration (FDA) has issued a drug safety notification warning against the use of frontline single-agent immune checkpoint inhibitors for patients with PD-L1-low expressing urothelial carcinoma. In August 2018, PD-L1 status has been incorporated into the labels for pembrolizumab and atezolizumab for existing frontline approvals in cisplatin-ineligible urothelial carcinoma. Therefore, this article shed light on a particularly relevant question from a clinical and scientific perspective but also raises technical issues regarding the method described.

First, the authors did not detail the staining protocol nor the antibody used to assess PD-L1 expression. Four PD-L1 assays have been FDA/ European Medicines Agency (EMA) approved in urothelial carcinoma, including the Dako 28-8, 22-c3 and the Vantana SP142 and SP263 monoclonal antibodies [2]. Divergent staining results have been reported in bladder cancer, leading to different detection rates of eligible patients for first-line treatment with immune checkpoint blockade [3]. The threshold $>1 \%$ for PD-L1 positivity was clearly defined by Chen et al [1]. However, it remains unclear which PD-L1 stained cells have been evaluated in this study (tumour cells? immune cells? both of them?). The authors should have reported the PDL1 score for each component of the tumour immune microenvironment. Indeed, the variability of PD-L1 expression across the type of stained cells may lead to variable relationship with ${ }^{18} \mathrm{~F}$ FDG uptake values.

Second, as immune checkpoint inhibitors are validated treatments in metastatic urothelial cancer, it would have been of interest to evaluate the correlation between ${ }^{18} \mathrm{~F}$-FDG uptake and PD-L1 expression in metastases rather than in the primary tumour. Indeed, the latter one is easily accessible by endoscopic transurethral resection. Five immune checkpoint inhibitors obtained accelerated approval by the FDA to treat metastatic bladder cancer [4], and molecular and functional imaging is increasingly recognized as a reliable tool for cancer staging $[5,6]$. Burgess et al, recently reported a discordance of PD-L1 immune cells expression between primary and metastatic urothelial carcinoma lesions [7]. Thus, the correlation between ${ }^{18} \mathrm{~F}-\mathrm{FDG}$ uptake and PD-1/PD-L1 expression in distant metastases may have been more variable.

Third, non-muscle invasive bladder cancer (NMIBC) stands for more than $70 \%$ of bladder cancers at time of diagnosis. NMIBCs are often detected as an infracentimetric thickening of the bladder wall. Approximately one third (13/38) of tumours analysed by Chen, et al, were NMIBC disease [1]. In this situation, ${ }^{18} \mathrm{~F}-\mathrm{FDG}$ uptake for most of the tumours $\leq \mathrm{pT} 1$ may have been underestimated due to partial volume effect. This phenomenon is well known to underestimate the uptake intensity in small or thin structures (i.e. $<8-12 \mathrm{~mm}$ approximately depending on the full width at half maximum (FWHM) of the reconstructed image resolution) [8]. Tumour size (presumably in the great axis) was included in the multivariate analysis, but 
the thickness was not. In addition, stromal lymphocyte infiltration is associated with tumour invasion depth in pT1 bladder cancer, suggesting that the immune infiltration is different between muscle-invasive and non-muscle invasive tumours [9]. Indeed, most of those tumours $\leq$ pT1 were PD-1 and PD-L1 negative, which may bias the results.

Arguably, predicting and monitoring the response to immune checkpoint inhibitors are becoming key issues in the near future. Numerous phase III trials evaluating anti-PD(L)1 immune checkpoint inhibitors are currently ongoing in both localized and advanced bladder cancer settings. Metabolic and molecular imaging will have a major impact on patients' management in the new era of cancer immunotherapy. The study reported by Chen et al, takes first step on a very promising way [1].

\section{References}

1. Chen R, Zhou X, Liu J, Huang G. Relationship between the expression of PD-1/PD-L1 and ${ }^{18}$ F-FDG uptake in bladder cancer. Eur J Nucl Med Mol Imaging. 2019. doi: 10.1007/s00259-018-4208-8.

2. Eckstein M, Erben P, Kriegmair MC, Worst TS, Weiß CA, Wirtz RM, et al. Performance of the Food and Drug Administration/EMA-approved programmed cell death ligand-1 assays in urothelial carcinoma with emphasis on therapy stratification for first-line use of atezolizumab and pembrolizumab. Eur J Cancer. 2019 Jan;106:234-243. doi: 10.1016/j.ejca.2018.11.007.

3. Bellmunt J, Powles T, Vogelzang NJ. A review on the evolution of PD-1/PD-L1 immunotherapy for bladder cancer: The future is now. Cancer Treat Rev. 2017 Mar;54:58-67. doi: 10.1016/j.ctrv.2017.01.007.

4. Rouanne M, Roumiguié M, Houédé N, Masson-Lecomte A, Colin P, Pignot G, et al. Development of immunotherapy in bladder cancer: present and future on targeting PD(L)1 and CTLA-4 pathways. World J Urol. 2018 Nov;36(11):1727-1740. doi: 10.1007/s00345018-2332-5

5. Girard A, Rouanne M, Taconet S, Radulescu C, Neuzillet Y, Girma A, et al. Integrated analysis of ${ }^{18} \mathrm{~F}$-FDG PET/CT improves preoperative lymph node staging for patients with invasive bladder cancer. Eur Radiol. 2019 Jan 21. doi: 10.1007/s00330-018-5959-0.

6. Öztürk H. Detecting Metastatic Bladder Cancer Using (18)F-Fluorodeoxyglucose PositronEmission Tomography/Computed Tomography. Cancer Res Treat. 2015 Oct;47(4):834-43. doi: $10.4143 /$ crt.2014.157

7. Burgess EF, Livasy C, Hartman A, Robinson MM, Symanowski J, Naso C, et al. Discordance of high PD-L1 expression in primary and metastatic urothelial carcinoma lesions. Urol Oncol. 2019 Jan 16. doi: 10.1016/j.urolonc.2019.01.002.

8. Soret M, Bacharach SL, Buvat I. Partial-volume effect in PET tumor imaging. J Nucl Med. 2007 Jun;48(6):932-45.

9. Rouanne M, Betari R, Radulescu C, Goubar A, Signolle N, Neuzillet Y, et al. Stromal lymphocyte infiltration is associated with tumour invasion depth but is not prognostic in high-grade T1 bladder cancer. Eur J Cancer. 2019 Feb;108:111-119. doi: 10.1016/j.ejca.2018.12.010. 